\title{
Derivation of Real-time Monitoring System for Power Supply System in Metro Substation
}

\author{
정호성 ${ }^{1}$, 박 영 ${ }^{1, a}$, 어수영 ${ }^{2}$ \\ (Hosung Jung', Young Park',a, and Sooyoung Oeu²)
}

\begin{abstract}
This paper introduces an overall system design of a real-time monitoring system that monitors condition of urban railway $\mathrm{AC} / \mathrm{DC}$ transformers, disconnecting switches, circuit breakers, regulators, and GIS (gas insulated switchgear). For effective diagnosis of urban railway facilities we developed optimized sensors and application technology. The proposed system is combined with wireless technology, implementing remote real-time monitoring of urban railway facilities. The derived real-time monitoring system for power facilities in urban railway substations will be applied not only to diagnose low voltage DC (direct current) railways but also to diagnose design of small power facilities of skyscrapers and apartments.
\end{abstract}

Key Words : DC railway, Monitoring system, Substation

\section{1. 서 론}

도시철도의 지속적인 건설과 경전철 등 다양한 전기철도 도입으로 전력설비의 실시간 감시시스템 과 진단시스템 구축이 요구되고 있다[1]. 고압설비 의 상태진단기술은 전기차 운행 중 실시간으로 이 루어져야 하고 도시철도 변전소가 무인으로 운영 됨에 따라 전력설비 자체의 온라인 상시감시 및 자기진단을 수행할 수 있는 기능도 이루어져야 한 다.[2] 현재의 전력설비 진단 및 모니터링 기술은 $765 \mathrm{kV}, 345 \mathrm{kV}$ 등 비교적 높은 전압의 변압기, 차단기, 정류기, GIS (gas insulated switchgear)등 절연기기의 부분방전등을 측정하여 진단하는 기술 이 개발되고 있다[3,4]. 그러나 도시철도 변전설비 의 경우 $\mathrm{DC} 1500 \mathrm{~V}$ 의 저전압설비이고 부분방전등 진단을 위한 기술 개발이 이루어지지 않고 있으며

1. 한국철도기술연구원 전철전력연구실 (경기도 의왕시 월암동 360-1)

2. 태광이엔시, TGE

a. Corresponding Author : ypark@krri.re.kr

접수일자 : 2010. 1. 12

1차 심사 : 2010. 3. 5

심사완료 : 2010. 3. 15
상태진단을 위해 일부 설치된 시스템은 독립적으 로 구축되어있고 전력시스템을 통합하고 상호 연 계하기 위한 시스템과 기초기술 연구도 수행되어 지지 않고 있다[5,6]. 또한 현재 전기철도 전력설비 의 진단시스템은 통합시스템이 아닌 각 전력기기 별로 산재되어 있어 종합적 상태를 실시간으로 전 력설비의 진단시스템과 모니터링 시스템 개발이 필요하다. 특히 현재 도시철도 전력설비의 설치기 준 등이 표준화 되어 있으므로 전력설비 고장을 사전에 검출하고 최적의 수명을 예측하기 위한 시 스템 또한 표준화되고 객관적인 상태 판단을 위한 시스템 도입이 필요하다[7,8].

본 연구에서는 도시철도 주요 전력설비 인 도시 철도용 $(\mathrm{AC} / \mathrm{DC})$ 변압기, 단로기, 차단기, 정류기, GIS의 실시간 모니터링 시스템 구현과 이를 통합 하는 시스템 설계하였다. 특히 도시철도 전력설비 의 효과적인 진단을 위한 센서개발 및 적용 기술 을 연구하였으며 통합진단시스템 구축방법에 대하 여 연구하였다. 또한 무선기반의 기술과 접목하여 단거리에서의 실시간 모니터링이 이루어지고 있으 며 이를 활용하여 도시철도 변전소의 종합적 상태 진단 기술의 설계 및 구축에 관하여 연구하였다. 


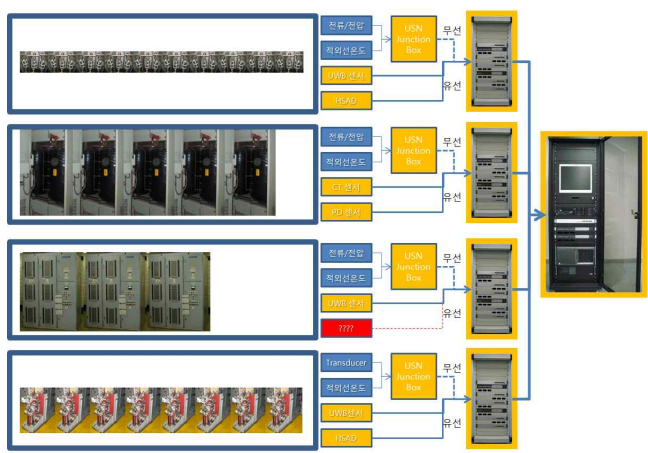

그림 1. 도시철도 $\mathrm{DC}$ 전력설비 실시간 진단시스 템.

Fig. 1. Picture of online diagnosis monitoring system for DC power units in metro.

본 논문에서 제안된 도시철도 전력설비 온라인 모니터링 및 진단기술은 지속적으로 건설되는 $\mathrm{DC}$ 도시철도 뿐만 아니라 $1.5 \mathrm{kV}$ 의 낮은 전압 기술이 므로 고층 빌딩 혹은 아파트단지 등 소규모의 전 력설비 진단을 위한 설계기술로 활용될 것이다.

\section{2. 시스템 설계}

\section{1 모니터링 장치}

도시철도 주요 전력설비 모니터링 시스템은 센 서부분인 DAS (data aquisition system)와 $\mathrm{CCU}$ (communication control unit) 그리고 Server 부분 으로 구성된다. 그림 1 에 도시철도 주요 전력설비 인 변압기, 교류차단기, 직류차단기, 도시철도 정류 기의 실시간 진단 시스템 구성도를 나타내었다. 각 설비의 구성은 도시철도 운영기관인 서울메트로, 광주도시철도공사, 서울도시철도공사, 인천공항공 사, 부산교통공사, 대구지하철공사에 전력설비 및 유지보수현황을 각각 조사하고 진단장비의 검사항 목, 장애사항 및 요구사항을 설문조사하여 그 결과 를 이용하여 온라인 진단항목을 결정하였다. 시스 템은 온라인 진단을 위한 센서, 하드웨어, HMI (human machine interaction) 로 정의되며 시스템 을 구성하는 계층구조 어느 수준에서나 적용이 가 능하다. 그림 1 과 2 에서 보는바와 같이 변압기에 적용하는 센서는 coupling sensor, $\mathrm{EHF}$ (extremely high frequency) CT (current transformer) sensor, 적외선 온도계, $\mathrm{CT}, \mathrm{PT}$ (potential transformer) 이고 교류차단기에 적용

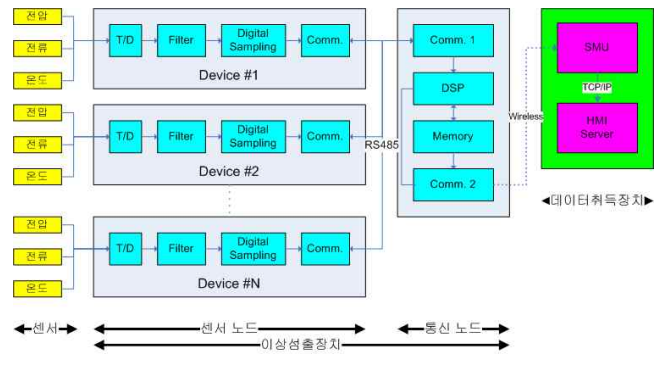

그림 2. 전력설비 상태 이상검출장치 Block diagram.

Fig. 2. Block diagram of power unit fault detection device.

하는 센서는 HSAD (high speed analog \& digital device), $\mathrm{EHF}$ sensor, 온도계, $\mathrm{CT}, \mathrm{PT}$ 이고 직류 차단기에 적용하는 센서는 $\mathrm{HSAD}, \mathrm{EHF}$ sensor, 온도계, $\mathrm{CT}, \mathrm{PT}$ 이고 정류기에 적용하는 센서는 기 계특성 검출 센서, $\mathrm{EHF}$ sensor, 온도계 및 $\mathrm{CT}$, PT 이다.

\section{2 이상검출장치 및 데이터취득장치 설계}

이상검출장치는 변압기, 차단기, 정류기의 전압, 전류, 온도, 부분방전을 측정하기 위한 창치로 확 장성 및 현장 케이블의 최소화를 위해 유비쿼터스 센서네트워크 (USN : ubiquitous sensor network) 기법을 도입하여 현장에 통신 노드 형태로 적용, $\mathrm{USN}$ 무선 네트워크를 통해 데이터 취득 장치로 취득한 정보를 전송하도록 설계하였다. 전압, 전류, 온도의 경우 장치는 크게 센서 노드와 통신 노드 로 구분되어지며 센서 노드는 각 $\mathrm{R}, \mathrm{S}, \mathrm{T}$ 3상의 1 차측과 2 차측 전압 및 전류, 그리고 2 개의 온도 측 정 module을 연결할 수 있도록 설계하였다. 통신 노드는 최대 48대까지의 센서노드를 연결하여 측 정된 데이터를 protocol 하여 데이터 취득 장치로 무선 통신하는 기능을 수행한다. 부분방전 이상검 출장치는 커플링센서를 이용한 6 채널의 변압기용 과 $\mathrm{EHF}$ 대역의 1 채널의 차단기 및 정류기로 구분하였다. 차단기 이상검출 장치는 $\mathrm{HSAD}$ 를 이 용하여 기계적 접점 메커니즘의 이상 유무와 점점 의 열화정도를 검측하도록 하였다. 데이터 취득장 치는 각 이상검출장치로부터 취득 되어진 다수의 다양한 신호 데이터를 통합하여 데이터취득 통신 장치로 정보를 전송하는 기능을 수행할 수 있도록 하였다. 통신 방식으로는 USN을 위한 RF통신 방 식을 지원하며 이상검출장치와의 통신을 위한 


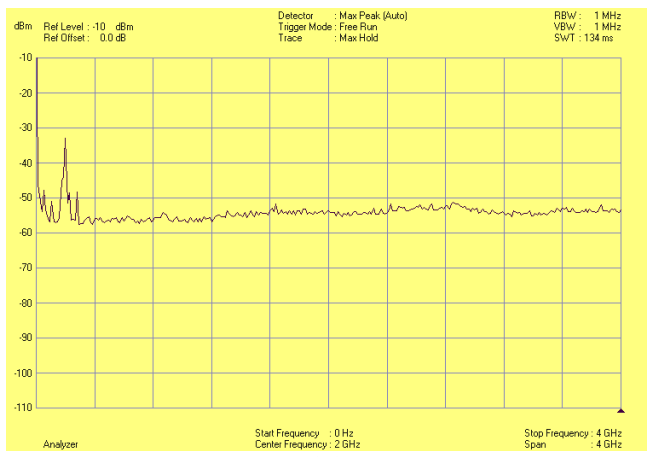

(a)

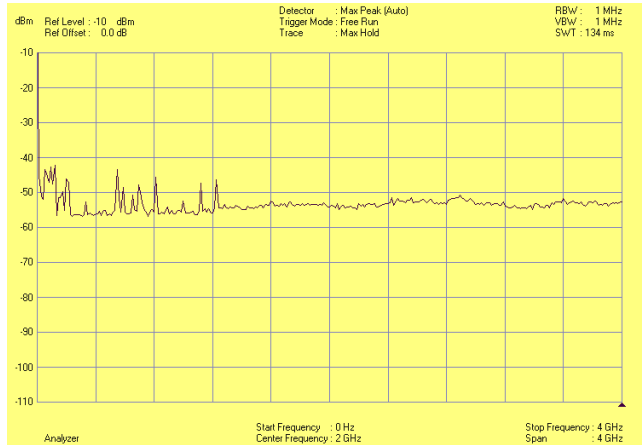

(b)

그림 3. 서울메트로 남태령 변전소 $\mathrm{DC}$ 전력설비 $4 \mathrm{GHz}$ 광대역 측정결과.

(a) 정류기 (DC $1500 \mathrm{~V}, 4,000 \mathrm{kw}),(\mathrm{b})$ 변압기

Fig. 3. Meausurement results of $4 \mathrm{GHz}$ broadband at Namtaeryeong substation DC power units.

(a) Rectifier (DC $1500 \mathrm{~V}, 4,000 \mathrm{kw}$ ), (b) Transformer

ethernet 포트와 데이터취득 통신장치와의 통신을 위한 ethernet 포트를 각각 구비하도록 설계하였으 며 사용자 편의를 위해 현장 정보의 입력 및 통신 상태 감시를 위한 화면 보기 기능을 구비하도록 설계하였다.

\section{3. 결과 및 고찰}

본 연구에서 제시하고자 하는 도시철도 변전소 전력설비 실시간 모니터링 장치는 무선 기반의 시 스템으로 설계되므로 무선 기반의 부분방전 측정 및 무선 데이터 전송에 방해가 될 수 있는 환경

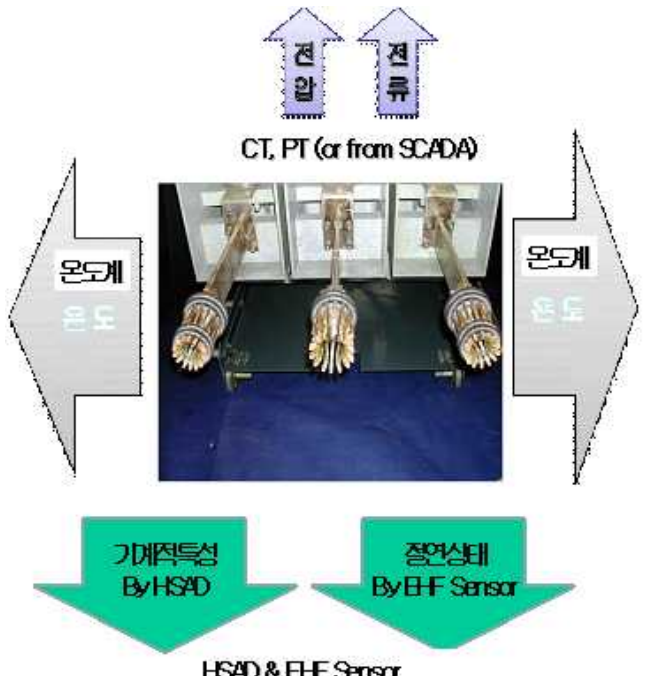

그림 4. 도시철도 변전소 차단기 열화진단을 위한 센서 구성도.

Fig. 4. Plot of sensors for metro power unit circuit breaker deterioration diagnosis.

노이즈를 분석하기 위하여 서울메트로 운행구간인 남태령 변전소에서 현장시험을 실시하였다.

그림 3에 $\mathrm{EHF}$ 센서를 이용한 정류기 및 변압기 측정결과인 광대역 스펙트럼 파형을 나타내었다. 측정결과 정류기의 경우 전자파 신호는 $500 \mathrm{MHz}$ 이하에서 발생하며, 변압기의 경우 상한선이 약 $1.2 \mathrm{GHz}$ 대역으로 나타나 무선 통신에서 사용하고 자 하는 $2.4 \mathrm{GHz}$ 대역에 영향을 미치지 않을 것으 로 보여 무선통신을 이용한 시스템 구성이 가능한 것으로 보인다[7,8].

도시철도 주요 전력설비의 진단은 변압기, 차단 기, 정류기, GIS 절연기기의 부분방전 등을 측정 하므로 본 논문에서는 종합적 시스템 구현을 위해 차단기를 모델로 분석하였다. 그림 4 에 차단기 열 화진단을 위한 구성도를 나타내었다.

단기 열화 시 발생되는 부분방전은 전자파 신호 측정, $\mathrm{AE}$ 신호 측정, $\mathrm{CT}$ 등을 사용하여 누설 전 류를 측정하는 방법 등 여러 가지 방법이 있지만, 현재 주로 사용되고 있는 방법은 전자파 신호 측 정 기법으로, 이 기법은 감도가 높고 다수의 전자 파 센서를 부착하였을 경우 부분방전의 대략적인 위치를 측정할 수 있으며, 패턴 분석을 통하여 부 분방전의 종류를 판별할 수 있다는 장점이 있다. 그림 5 는 차단기 내부 부분방전 발생에 의한 전자파 


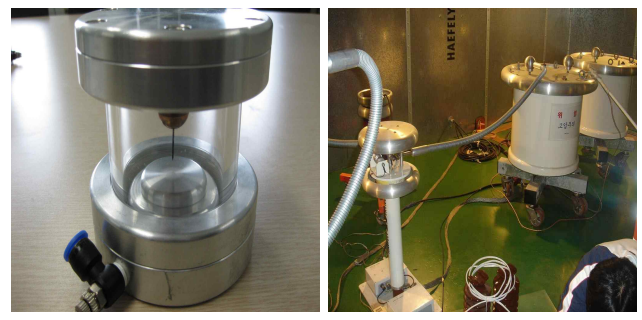

그림 5. 부분방전 셀 및 전압 인가 장치 사진.

Fig. 5. Partial discharge cell and voltage application device.

신호의 주파수 대역을 분석하기 위해 부분방전의 모의 - 발생에 사용한 부분방전 셀의 사진이다.

셀의 내부는 일반 대기와 같은 성분의 공기로 채워졌으며, 사용한 부분방전 셀은 차단기 내부에 서 발생 가능한 돌출부 결함을 모의한 셀이다. 실 험은 한양대학교 퓨전연구센터의 고전압 차폐실험 실에서 이루어졌으며, 모의 전극에 전압을 인가하 고 부분방전의 크기를 측정하기 위한 부분방전 측 정 장치로는 HAEFELY TRENCH 사의 TE-571 장비를 사용하였다. 이 설비의 전압 인가장치는 $\mathrm{AC} 100 \mathrm{kV}$ 까지 전압을 인가할 수 있고, 전압 인 가용 변압기는 특수하게 제작되어 변압기 자체에 서 코로나가 발생하지 않는 특성을 가지고 있다.

부분방전의 크기를 측정하기 위한 기법은 국제 규격인 IEC 60270에 의거하여 설계되어 있으며, 연결된 $\mathrm{PC}$ 를 사용하여 부분방전의 방전량 $(\mathrm{pC})$ 과 방전 형태를 화면상으로 볼 수 있는 장비이다. 그 림 6은 모의시험 설비를 사용하여 부분방전의 크 기를 증가시켜가며 부분방전 신호의 주파수대역을 분석한 결과이다.

$5 \mathrm{pC}$ 발생 시부터 약 $1 \mathrm{GHz}$ 대역에서 신호가 측정되었으며, 부분방전량이 늘어남에 따라 $1 \mathrm{GHz}$ 대역만이 아닌 $0.6 \mathrm{GHz}$ 대역, $1.3 \mathrm{GHz}$ 대역, 1.6 $\mathrm{GHz}$ 대역 등 측정되는 주파수 범위가 광대역으로 늘어남을 알 수 있다. 본 실험조건에서는 $25 \mathrm{pC}$ 이상으로 부분방전을 발생시킬 경우 flashover 현 상이 발생하여, $3 \mathrm{GHz}$ 이상의 대역에서의 신호발생 유무는 파악하지 못하였으나, 부분방전 증가에 따 라 검출되는 전자파의 주파수 대역이 광대역으로 늘어나는 것으로 미루어 보아 기존의 $\mathrm{UHF}$ 대역 측정 $(500 \mathrm{MHz} \sim 1.5 \mathrm{GHz})$ 을 $\mathrm{EHF}$ 대역까지 확장 하여 $(500 \mathrm{MHz}$ 약 $5 \mathrm{GHz})$ 시스템을 설계할 경우 부분방전 검출에 더욱 유리할 것으로 보인다. 또한 차단기의 경우 단순 절연이상에 의한 전기적인 사

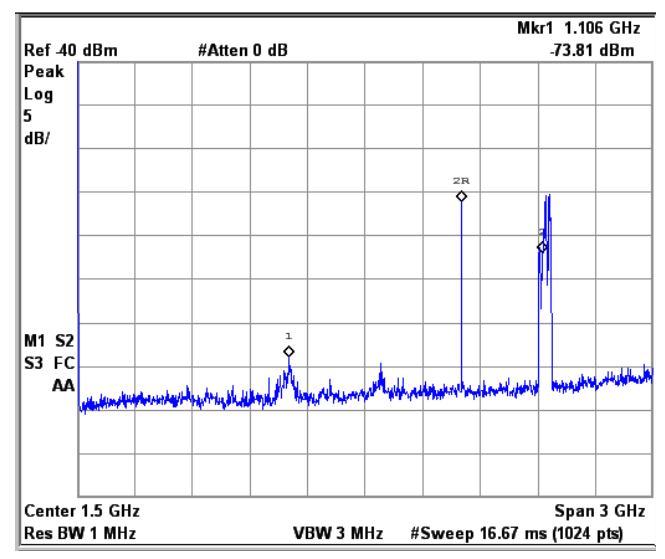

(a)

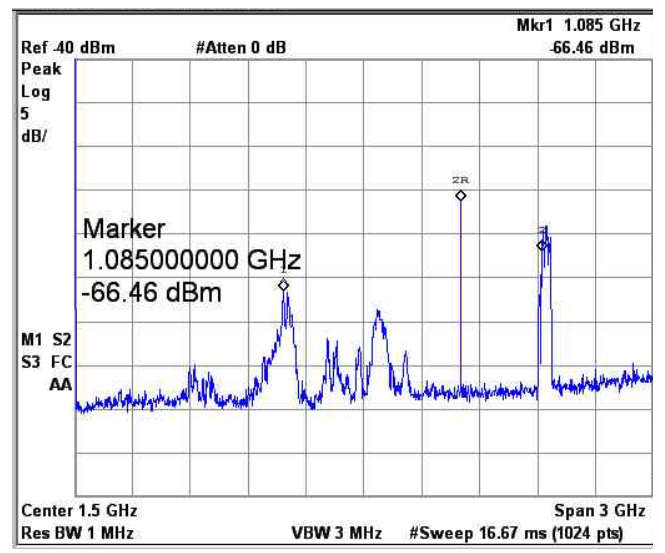

(b)

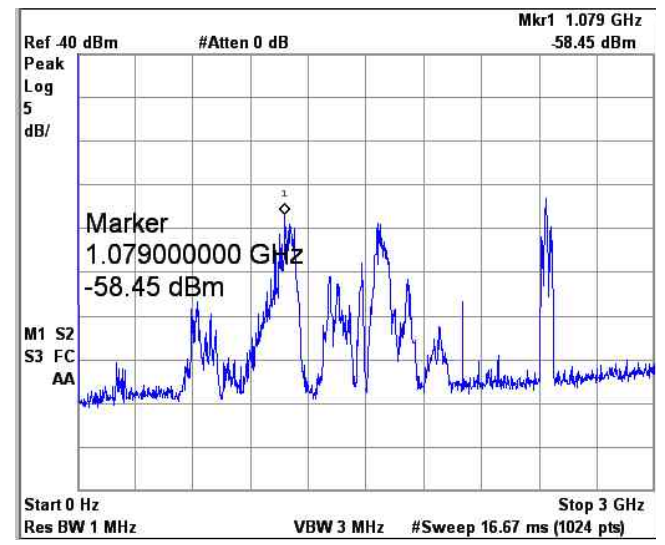

(c)

그림 6. 부분방전 스펙트럼 파형 측정결과 (a) $5 \mathrm{pC}$, (b) $15 \mathrm{pC}$, (c) $25 \mathrm{pC}$

Fig. 6. Measurement results of partial discharge spectrum waves.

(a) $5 \mathrm{pC}$, (b) $15 \mathrm{pC}$, (c) $25 \mathrm{pC}$ 
고도 많지만, 스위치 동작 부분의 기계적인 불량에 의한 기계적인 사고의 점유율도 상당히 높으며, 도 시철도 운영자들의 감시항목 요구사항 분석결과에 서도 높은 비율을 차지하고 있다. 이러한 기계적인 이상을 측정하기 위해 차단기의 동작전류를 측 정-분석하는 센서와 동작전류 측정장치를 차단기 이상검출장치에 적용한다.

\section{4. 결 론}

본 논문에서는 도시철도 주요 전력설비 인 도시 철도용 $(\mathrm{AC} / \mathrm{DC})$ 변압기, 단로기, 차단기, 정류기, $\mathrm{GIS}$ 의 실시간 모니터링 시스템 구현과 이를 통합 하는 시스템 설계에 관하여 기술하였다. 통합시스 템의 구성은 도시철도 운영기관인 서울메트로, 광 주도시철도공사, 서울도시철도공사, 인천공항공사, 부산교통공사, 대구지하철공사에 전력설비 및 유지 보수현황을 각각 조사하고 진단장비의 검사항목, 장애사항 및 요구사항을 설문조사하여 그 결과를 이용하여 온라인 진단항목을 결정하고 무선기반으 로 설계하였다. 무선기반의 환경 노이즈를 분석하 기 위하여 서울메트로 운행구간인 남태령 변전소 에서 현장시험을 $\mathrm{EHF}$ 센서를 이용한 정류기 및 변압기 측정결과 정류기의 경우 전자파 신호는 $500 \mathrm{MHz}$ 이하에서 발생하며, 변압기의 경우 상한 선이 약 $1.2 \mathrm{GHz}$ 대역으로 나타나 무선 통신에서 사용하고자 하는 $2.4 \mathrm{GHz}$ 대역에 영향을 미치지 않을 것으로 나타났다. 모델시험 결과 $\mathrm{UHF}$ 대역 측정 $(500 \mathrm{MHz} \sim 1.5 \mathrm{GHz})$ 을 $\mathrm{EHF}$ 대역까지 확장 하여 $(500 \mathrm{MHz} \sim$ 약 $5 \mathrm{GHz})$ 시스템을 설계할 경 우 부분방전 검출이 보다 민감도를 나타낼 수 있 었으며 본 논문에 결과는 도시철도 변전소뿐만 아 니라 $1.5 \mathrm{kV}$ 의 낮은 전압 기술이므로 고층 빌딩 혹은 아파트단지 등 소규모의 전력설비 진단을 위 한 설계기술로 활용될 것이다.

\section{감사의 글}

본 연구는 건설교통부 도시철도표준화2단계연구 개발사업의 연구비지원(07도시철도표준화A01)에 의해 수행되었습니다.

\section{참고 문헌}

[1] 나해경, 박영, 조용현, 이기원, 박현준, 오수영, 송준태, "실시간 계측시스템을 이용한 전차선 로 특성 측정”, 전기전자재료학회논문지, 20 권, 3호, p. 281, 2007.

[2] 박영, 정호성, 김형철, 권삼영, 박현준, “철도 전 기시설물의 상태진단 향상 기법”, 한국전기전 자재료학회 2007추계학술대회논문집, p. 500 2007.

[3] 김경화, 이동준, 곽희로, "GIS내 파티클의 상태 에 따른 부분방전 신호의 분석”, 한국조명전기 설비학회, 14권, 1호, p. 67, 2000.

[4] 권동진, 박재준, “변압기 부분방전 상시 감시기 법에 관한 연구”, 전기전자재료학회논문지, 14 권, 12호, p. 1032, 2001.

[5] 이흥재, 강현재, "765 kV 변전소의 고장진단 전문가 시스템에 관한 연구”, 전기학회논문지 58권, 7호, p. 1276, 2009.

[6] 권동진, 강연욱, 주병수, 이옥배, 이호진, "345 $\mathrm{kV}$ 의령변전소 예방진단시스템의 데이터 분 석”, 대한전기학기학회 2002하계학술대회논문 집, C권, p. 1899, 2002.

[7] 권동진, 심응보, 정길조, 김범진, 김종화, 유연 표, 은종영, 신한철, "765 kV 신가평, 신태백 변전소 예방진단시스템”, 대한전기학회 2002하 계학술대회논문집, C권, p. 169, 2002.

[8] 이상화, 윤영우, 추영배, 강동식, "운전중 부분 방전 진단시스템을 위한 복합 잡음 제거 기 법”, 전기학회논문지, 58권, 2호, p. 342, 2000. 